\title{
A simple quantitative assay of tissue plasminogen activator
}

\author{
LINDA DE COSSART, RW MARCUSON \\ From the Department of Surgery, Hope Hospital, Eccles Old Road, Salford M6 8HD
}

SUMmARY A simple method for the quantitative assay of tissue plasminogen activator is described. Human veins and uterus obtained at operation are disintegrated in a membrane disintegrator at $-70^{\circ} \mathrm{C}$ and a known weight of the powder, suspended in buffered saline and thoroughly mixed. Assay of the dilutions of this homogenate on isotope-labelled fibrin clots gives straight line plots of $\log$ weight against $\log$ activity of the dilution and the sample activity is calculated from this.

The method has been compared with the conventional histochemical technique. A highly significant correlation between the results of the two methods has been obtained $(r=0.79$; $\mathrm{p}<0.001)$.

The principal methods currently used to measure plasminogen activator in tissue are the potassium thiocyanate extraction technique ${ }^{1}$ and the histochemical fibrin slide method first described by Todd $^{2}$ and modified by Pandolfi et al. ${ }^{3}$ The latter method has been used most commonly to study the relation between disease and tissue plasminogen activator $^{4-10}$ but despite various scoring systems remains semiquantitative. We have developed a more quantitative technique in which dilutions from homogenates of tissue are assayed on fibrin clots labelled with ${ }^{125}$ I fibrinogen. The results have been compared with those obtained by the histochemical method.

\section{Material and methods}

Samples of vein and uterus obtained at operation or after amputation were immediately rinsed in buffered saline at $4^{\circ} \mathrm{C}$ to remove any blood contamination. They were dried on filter paper and carefully divided into two pieces which were frozen to $-70^{\circ} \mathrm{C}$ without delay. One piece was kept at $-70^{\circ} \mathrm{C}$ until assayed by an homogenate technique. The other piece was frozen onto a chuck immersed in liquid nitrogen using mounting medium. This chuck was kept in a sealed container in a vacuum flask containing cardice in $\mathrm{a}-70^{\circ} \mathrm{C}$ freezer until assayed by the histochemical technique described by Pandolfi et $\mathrm{al}^{3}$ modified as described below.

Accepted for publication 2 February 1982
HOMOGENATE TECHNIQUE

A weighed sample of the tissue was disintegrated in $\overrightarrow{0}$ a Mikrodismembrator II (B Braun) at $-70^{\circ} \mathrm{C}$ fơ ? $25 \mathrm{~s}$. The powdered remains were resuspended if. $2 \mathrm{ml}$ buffered saline at $4^{\circ} \mathrm{C}$ and mixed thoroughly? Four further dilutions of this homogenate were made to give five aliquots of dilution $1 / 1,1 / 2,1 / 4$, $1 / 8,1 / 16(\mathrm{wt} / \mathrm{vol})$. Two $30 \mu \mathrm{l}$ aliquots of each dilution were placed on heated and unheated fibrin clots prepared as follows:

\section{Unheated}

Human fibrinogen grade $\mathrm{L}$ (Kabi) was dissolved in Michaelis-buffered saline ( $\mathrm{pH} \mathrm{7.4)}$ to a working solution of $0.01 \% \mathrm{wt} / \mathrm{vol}$. ${ }^{125}$ I fibrinogen $110 \mu \mathrm{C}$ was dissolved in $2 \mathrm{ml}$ of the buffered saline in a sealed container. This was added to the fibrinogen solution to give a working concentration of $0.05 \mu \mathrm{C} / \mathrm{ml}$. Of this solution $10 \mathrm{ml}$ were clotted in a $9 \mathrm{~cm}$ Petri dish (Sterilin) with $0.5 \mathrm{ml}$ of a solution of calcium thrombin (Leo) $20 \mathrm{U} / \mathrm{ml}$. The plates were allowed to consolidate at room temperature for one hour. The same batch of fibrin was used for all assays. After inoculation with the dilutions of the homogenate the fibrin plates were incubated on a level surface at $37^{\circ} \mathrm{C}$ for $22 \mathrm{~h}$. A $30 \mu \mathrm{l}$ sample of urokinase (Leo) 50 $\mathrm{U} / \mathrm{ml}$ was placed on each fibrin plate to ensure similarity of the counts released by each fibrin plate. Even distribution of the ${ }^{125}$ I fibrinogen was checked by assay of 10 samples of urokinase on these plates freshly prepared $(5975 \pm 244)$ and after two weeks' 
storage $(5023 \pm 115)$. Adjustment was made for any difference in counts.

\section{Heated}

Heated plates were similarly prepared but in a glass Petri dish to allow heating in an oven at $80^{\circ} \mathrm{C}$ for 30 min to destroy plasminogen according to the method described by Lassen.'

After incubation the volume of fibrin lysed was aspirated into a counting tube and the hole in the fibrin washed with $1 \mathrm{ml}$ of water which was also placed in the counting tube. The tube was counted in a gamma counter for $10 \mathrm{~min}$. The activity of the aliquot was expressed as the mean of the corrected counts per minute released by each $30 \mu \mathrm{l}$ sample.

Regression lines for the log ccpm and the log weight of vein $(\mu \mathrm{g})$ were drawn for each dilution. The activity score of the specimens was calculated from the graph and was equivalent to the counts released by one microgram of tissue. The regression lines of a high activity sample and a low activity sample are shown in Fig. 1. The activity score for each specimen is the intercept of the regression line on the " $y$ " axis.

\section{HISTOCHEMICAL TECHNIQUE}

The method described by Pandolfi et $a l^{3}$ was used with the following modifications: $0.06 \mathrm{ml}$ of the fibrinogen solution and $0.01 \mathrm{ml}$ of the thrombin solution were mixed on a microscope slide and spread over an area of $10 \mathrm{~cm}^{2}$. The slides were allowed to consolidate in a moist chamber for $30 \mathrm{~min}$ and used within one hour of preparation. Four 8-10 $\mu \mathrm{m}$ frozen sections were placed on each fibrin slide and five

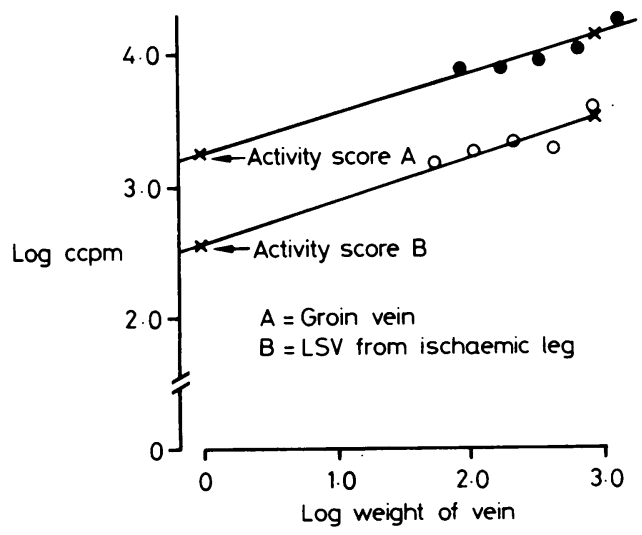

Fig. 1 The regression lines of log weight against log ccpm of two samples $A$ and $B$. The activity score is the intercept on the " $y$ " axis.
Table 1 Homogenate results in specimens studied

\begin{tabular}{lc}
\hline Specimen & Score \\
\hline Top long saphenous vein & 1948 \\
Top long saphenous vein & 1943 \\
Superficial inferior epigastric & 1763 \\
Body of uterus & 1593 \\
Top long saphenous vein & 1520 \\
Top long saphenous vein & 1400 \\
Calf vein saphenous specimen & 1378 \\
Body of uterus & 1375 \\
Top long saphenous vein & 1012 \\
Calf long saphenous vein (amputation) & 999 \\
Calf varicose vein & 850 \\
Amputation long saphenous vein & 841 \\
Amputation long saphenous vein & 705 \\
Top long saphenous vein & 664 \\
Amputation long saphenous vein & 643 \\
Amputation long saphenous vein & 404 \\
Amputation long saphenous vein & 363 \\
Amputation long saphenous vein & 328 \\
Calf varicose vein & 316 \\
Amputation long saphenous vein & 315 \\
Calf varicose vein & 144 \\
Amputation calf long saphenous vein & 40 \\
\hline
\end{tabular}

*Activity score of specimens was calculated from the graph (see Fig. 1) and was equivalent to counts released by $1 \mu \mathrm{g}$ of tissue.

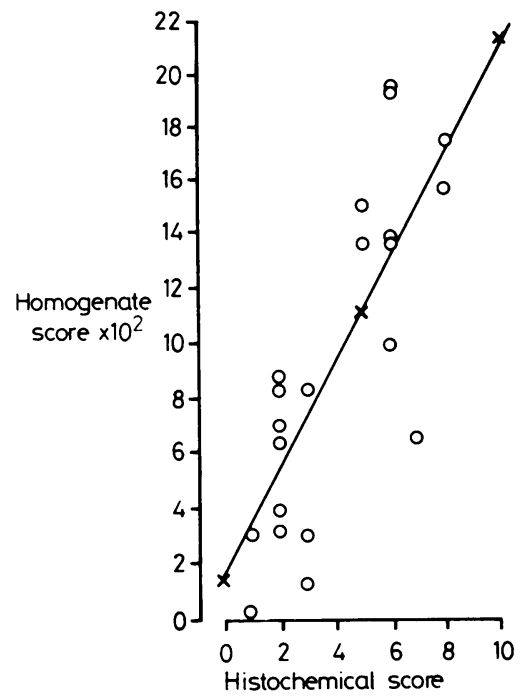

Fig. 2 Scatter diagram showing the correlation of the homogenate score ( $y$ axis) and the histochemical score ( $x$ axis). $X-X=$ regression line and $r=0.79$

fibrin slides were prepared for each specimen. They were incubated in a moist chamber at $37^{\circ} \mathrm{C}$ for 5,10 , 20 and $30 \mathrm{~min}$. The fifth slide was used as a control and was placed in the formalin without incubation. Scoring was as follows: $0=$ no lysis; $1=$ pinhole lysis; $2=$ distinct areas of lysis; $3=$ large areas of lysis but no coalescence; $4=$ massive lysis. The mean score for each slide was determined and the 
Table 2 Results of the two assays on the long saphenous vein from the leg obtained immediately after amputation

\begin{tabular}{lll}
\hline Specimen & Homogenate score* & $\begin{array}{l}\text { Histochemical } \\
\text { score }\end{array}$ \\
\hline 1 & 328 & 2 \\
2 & 841 & 2 \\
3 & 643 & 2 \\
4 & 999 & 2 \\
5 & 404 & 2 \\
\hline
\end{tabular}

*See footnote to Table 1 .

activity of the specimen was the cumulative score for each sample.

\section{Results}

Twenty samples of vein from different sites and two specimens of uterus were examined by both methods. Table 1 shows the results obtained by the homogenate technique and the site of origin of the veins.

The correlation of the results obtained by the two methods is shown in Fig. 2. The correlation coefficient $\mathrm{r}=0.79$.

A range of activity was apparent from the homogenate score which was not indicated by the histochemical score. This is demonstrated in Table 2 by the results of the assays on adjacent pairs of samples taken from five sites on a single long saphenous vein removed from the calf of an amputated limb.

There was no lysis on any of the heated plates.

\section{Discussion}

A new method for measuring plasminogen activator in tissue has been described and the results obtained compared with those by an established technique. A highly significant correlation between the two sets of results has been demonstrated.

The homogenate technique has several advantages in that it is simple to perform, is technically easier than the histochemical method, is quantitative and free from subjective error. Venous tissue is difficult to homogenise in a Potter's homogeniser as used in the potassium thiocyanate technique but the Mikro dismembranator II, a percussive ball homogeniser, is particularly good for this. It is often used for the preparation of tissue samples for analysis by infrared, $x$-ray, and electron spectroscopy. Disintegration takes place at $-70^{\circ} \mathrm{C}$ which makes the tissue brittle and ensures the tissue is kept at low temperature during the procedures. Samples of vein $(20-40 \mathrm{mg})$ are disintegrated in $25 \mathrm{~s}$ and we have confirmed by electron microscopy of the debris that complete breakdown of the cell is achieved. The homogenate is easily suspended in buffered saline.

The histochemical technique gives useful information on the site of activity of the plasminogen activator and has been widely used in clinical studies in veins. ${ }^{4-7}$ Nevertheless, the method requires considerable expertise to produce satisfactory results and remains semiquantitative. No results of assay of small veins by the potassium thiocyanate extraction technique have been reported.

Johnson and Mansfield ${ }^{12}$ attempted to quantify activator release from whole vein by incubation of the vein endothelial surface down on an ${ }^{125}$ I fibrin clot. Their method however does not correlate with the results by the histochemical technique. ${ }^{13}$

Using the homogenate technique we have been able to quantify plasminogen activator in various tissues and have shown that thigh long saphenous vein has considerably higher activity than calf long saphenous vein (unpublished data).

We conclude therefore that this new homogenate technique is a useful and viable method for the investigation of tissue plasminogen activator.

This work was made possible by a grant from the Manchester Regional Health Authority. We are grateful to Professor Miles Irving for the use of facilities in the Department of Surgery, Hope Hospi tal. We are especially grateful to Dr Jean Thomson Withington Hospital, who gave invaluable help in preparing this paper.

\section{References}

' Astrup T, Albrechsen OK. Estimation of the plasminogen activator and the trypsin inhibitor in animal and human tissue. Scand J Clin Lab Invest 1957;9:233-43.

${ }^{2}$ Todd AS. Fibrinolysis autographs. Nature 1958;181:495-6.

${ }^{3}$ Pandolfi M, Nilsson IM, Robertson B, Isaacson S. Fibrinolytic activity of human veins. Lancet 1967;2:127-8.

4 Astedt B. Low fibrinolytic activity of veins during treatment with e ...inyl estradiol. Acta Obstet Gynaecol Scand 1971;50:27983.

s Browse NL, Gray L, Jarrett PEM, Morland M. Blood and vein wall fibrinolytic activity in health and vascular disease. $\mathrm{Br} \mathrm{Med}$ J 1977;i:478-81.

- Isaacson S, Nilsson IM. Defective fibrinolysis in blood and vein walls in recurrent idiopathic venous thrombosis. Acta Chir Scand 1972;138:313-9.

' Nicolaides AN, Clark CT, Thomas RD, Lewis JD. Fibrinolytic activator on the endothelium of the veins in the lower limb. Br J Surg 1976;63:881-4.

${ }^{8}$ Cunliffe WJ, Dodman BA, Dodman EA, Webster J. A method for the quantitative assessment of tissue fibrinolysis. In: Davidson JF, Samama M, Desnoyers PC eds. Progress in chemical fibrinolysis and thrombosis. Vol 1. New York, Raven Press: 1975:241-7.

9 Kwaan HC, Astrup T. Demonstration of fibrinolytic activity by the histochemical fibrin slide technique. Lab Invest 1967;17:140-4. 
${ }^{10} \mathrm{Kwaan}$ HC, Astrup T. Localisation of fibrinolytic activity in the eye. Arch Pathol 1963;76:596-601.

plasminogen activator assay. Thromb Haemost

"Lassen M. Heat denaturation of plasminogen in the fibrin plate method. Acta Physiol Scand 1952;27:371-6.

12 Johnson RH, Mansfield AO. A new method for the detection of the plasminogen activator content of vein walls. Acta Haematol 1978;60:243-9.

${ }^{13}$ Marsh NA, Gaffney PJ. The rapid fibrin plate-a method for 1977;238:545-51.

Requests for reprints to: Dr Linda de Cossart, Department of Surgery, Hope Hospital, Eccles Old Road, Salford M6 8HD, England. 